\title{
Strategy Optimizing Marine Industry through Sustainable Human Capital Development: Indonesia Perspectives
}

\author{
John Tampil Purba \\ Departement of Management Business School Pelita Harapan University, Tangerang, Indonesia \\ Email:.jpoerba88@gmail.com
}

\author{
Doi:10.5901/mjss.2015.v6n5s5p129
}

\section{Abstract}

\begin{abstract}
The idea of President of Indonesia, Joko Widodo, in developing the nation to be a global maritime axis by enhancing economy activities through inter-island connectivity, and upgrading port infrastructure within the Indonesian archipelago. It provides a variety of products with content high economic value such as the high potential of biotic natural resources for the marine industry, mining, tourism, energy, and transportation. Sustainable Human Capital Development becomes powerful enabler in optimizing marine industry also the resources. With the population approximately 250 million is able to offer human capital development to translate the idea into a sizeable market needs to support the development various sectors of the marine industries. This study used descriptive and quantitative analysis by collecting related secondary data which selected accordingly. This paper discusses the Sustainable Human Capital Development which considered potentially optimize the marine industry over the country. Due to a lot of obstacles in terms of shortage qualified human resources in maritime affairs, proposed strategy for human capital development especially for the purpose of this study becomes recommendation from the researcher to be the government priority to utilize the available great resources inside the country that can impact towards growth and development economy of the nation in the future.
\end{abstract}

Keywords: Strategy optimizing, marine industry, sustainable development, human capital, Indonesia perspectives.

\section{Introduction and Background}

Indonesian economy will be affected even directly or indirectly with enforced by ASEAN Free Trade Area (AFTA) that gradually in the scope of the ASEAN countries since 2003. By the end of this year 2015, the ASEAN Economic Community (AEC). Thus, the free trade will soon come into force and will take place entirely. Then, start from this year free trade throughout the Asia Pacific region will be implemented. Meanwhile, from the external side is definitely global competition will get stronger effect on national development in the future. There are a lot people in this country can employed and involved in maritime activities and economy because this industry consists of many activities in the field of economy as defined by Dervojeda, K. et al (2012) maritime industries include all enterprises engaged in the business of designing, constructing, manufacturing, acquiring, operating, supplying, repairing and/or maintaining vessels, or component parts thereof: of managing and/or operating shipping lines, and customs brokerage services, shipyards, dry docks, marine railways, marine repair shops, shipping and freight forwarding services and similar enterprises.

The Significance of this study; National Planning Agency or Bappenas (2014) marine development program in the National Medium Term Development Plan (RPJMN) 2015-2019 conducted by promoting the role of the marine economy and national marine development synergy with the target: marine resources for economic development and well-being of a society of fishermen and coastal. The role of natural resources can be seen from its contribution to GDP in 2002 reached 24.8 percent and employment reached 48 percent. Bappenas (2014) labour competitiveness one of which is reflected by the expertise and skills of workers respond to an increasingly open market. Surya, C T. Ade (2014) construction and development of the maritime sector is a priority for the government of Jokowi (the President RI), as in fact, Indonesian maritime sector has a huge potential that until now only about 20 percent are successfully utilized. What are happens in reality in world of human resources especially for responding the maritime aspects? APEC (2014) despite domestic and international efforts and initiatives, to date there are still knowledge gaps which undermine our ability to pursue marine sustainable development. The other problems; there are only a few education and or training providers to produce the human resources on maritime skills as Othman, Rosni M. (2014) nowadays, not much of training work has been done at rationalizing the number and optimizing the facilities in the maritime education due to the escalating of the cost to maintain these facilities. Therefore the new approach of teaching and learning mechanism for the future maritime education system should be developed. Due to the enhance that plans, development human capital for the nation is 
becoming compulsory in order to achieve the expertise and skills of people for responding the needs and competitiveness. The aims and objectives of this study are to give the recommendations to the government of Indonesia to optimize the human capital development in responding to changes in economic environment which has direct and indirect effects for country.

\section{Literature Review}

The previous study said; that develop the nation strategically the human capital development is a must, in sustaining the growth of economy as Cotten, Ann (2007) human capital emphasizes the strategic importance of an organization's workforce. In the knowledge economy, the collective set of knowledge, skills, abilities, and competencies the human capital residing in an organization's workforce is arguably the most important determinant of an organization's ability to sustain long-term success. With strategic human capital management, is about aligning an organization's human capital its people with its business plan to achieve its mission; ensuring that an organization currently has and will continue to have the right people with the right skills in the right job at the right time performing their assignments efficiently and effectively.

The absence of human capital development programs could be consequence to the organization performance and will be going into critical conditions. As argued by Purba, J. T. (2014) as cited in his paper; stated that skills are critical for both workers and the enterprises that employ them, enabling workers to attain decent work and manage change, and enabling enterprises to adopt new technologies and enter new markets (ILO report 2013). Asyali, E. et al (2010) human resource is one of the leading determinants in maritime transport industry and both the industry and the individual shipping companies consider human resources strategies as an important area of research. According to Barsan, E. et al (2012) a maritime company can keep a competitive advantage for medium and long term, by focusing on human resources strategies that can reach the following specific actions: the human resources orientation. Entering maritime organizations the human capital development in maritime business can conduct by various ways; Felicia, Surugiu, et al (2010) in maritime business, competitive firms are the ones that provide qualitative transport services at a competitive price. Entry level solutions are pre-sea courses for cadets, counseling, distance learning, STCW courses and system training. Nadeak, B. \& Purba, John T. (2014) human capital becomes the main concern in the today's issues in any organizations around the world, the capabilities of any person in implementing of his/her job descriptions responsibilities giving impact to the organization where he/she works. The skills and competencies of human resources in the organizations can convey the sustainability of themselves. Human capital development can be done through education development as Suprapto, Djoko (2002) development of education in Indonesia involves restructuring the system to be more responsive to the dynamics of the development and rapid changes of societal needs. It aims to establish a management system that will be used as a basis of implementation of higher education as a sub-system of the national education system.

\section{Methodology}

This research methodology is using combining of qualitative and quantitative analysis (Bogdan, et al, 1998 and Reaves, C., 1992) in order to determine sustainable human capital for strategy optimizing marine industry in Indonesia, the gap analysis also used. The research data in this study is achieved through collected data from secondary resources such as from official report publications of Ministry of Maritime Affairs and Fisheries Republic Indonesia in the year of 2013-2014, National Planning Agency RI report 2014 and other data resources related. Limitation of this study only focused on human capital in maritime industry from data selected then analyzed and interpreted accordingly. This study is focused to analyze the findings and to observe how important are human capital development to overcome the obstacle of human resources in optimizing the national maritime industry. It is highly recommended to do more researches in the mean of national maritime industry in the future.

\section{Findings and Discussion}

Agreed to Surya, C.T. Ade (2014) that Indonesia has a genetic diversity, species, and the highest in the world's marine ecosystems are known as mega-marine biodiversity. Potentially, the total economic value of fisheries products and Indonesian marine biotechnology products is estimated at around IDR. 984 trillion per year. Although there is no calculation of the economic potential of marine tourism, but if we compare with the state of Queensland in Australia with a long coastline of about 9,800 miles, but only able to generate foreign exchange nautical tourism IDR. 24 trillion per year. 
Thus, Indonesian marine eco-tourism economic potential is enormous.

Review of Regulatory Reform in Indonesia, OECD (2012) stated that Indonesian government has made significant strides in developing and implementing a better regulatory framework for competition and efficiency in the field of logistics. Recent changes to the Law No. 17 Year 2008 on the voyage and Act No. 23 of 2007 the potential to transform the railway industry and maritime Indonesia radically. If we pay attention to human capital in Asia where Indonesia is still very underdeveloped, it is evident from the table that served the OECD (2013) and then as follows:

Table 1. Human capital development indicators in Asia

\begin{tabular}{|c|c|c|c|c|c|c|c|c|c|c|c|c|}
\hline & \multirow{3}{*}{ 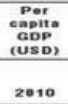 } & \multicolumn{2}{|c|}{$\begin{array}{l}\text { Aduit itteracy rate } \\
\text { (above is in age) }\end{array}$} & \multicolumn{7}{|c|}{ Gross enrot ment ratio $(\%)$} & \multicolumn{2}{|c|}{$\begin{array}{l}\text { Human Development } \\
\text { Index (New scate) }\end{array}$} \\
\hline & & \multirow{2}{*}{$\begin{array}{l}\text { Femate } \\
200 \text {-es }\end{array}$} & \multirow{2}{*}{$\begin{array}{l}\text { Mate } \\
2005-09\end{array}$} & \multicolumn{2}{|c|}{ Primary sehool } & \multicolumn{2}{|c|}{ Higher Sehool } & \multicolumn{2}{|c|}{ Tertiary education } & \multirow[t]{2}{*}{ rear } & \multirow{2}{*}{$\begin{array}{l}\text { HDI } \\
2010\end{array}$} & \multirow{2}{*}{$\begin{array}{c}\text { Ranking } \\
2010\end{array}$} \\
\hline & & & & Fermate & male & Fernale & mate & Femate & male & & & \\
\hline singapore & 35022 & 91 & 97 & 95 & 95 & 73 & 75 & 40 & 47 & 2008 & 0.846 & 27 \\
\hline Hong Kong. China & 24628 & 91 & 97 & 105 & 105 & se & 36 & 34 & 33 & 2008 & 0.862 & 21 \\
\hline Chima & 3556 & a7 & 95 & 111 & 111 & 78 & $n$ & 23 & 23 & 2008 & o.ees & o1 \\
\hline Lapan & 92600 & so & 90 & 100 & 100 & 101 & 101 & 54 & 62 & 2000 & 0.084 & 1 \\
\hline Korea & 16401 & 98 & 98 & 104 & 104 & 94 & 98 & อง & 65 & 2008 & 0.877 & 12 \\
\hline chanese Taipel & 16552 & so & 96 & 102 & 102 & 90 & 90 & as & 70 & 2008 & - & - \\
\hline Indonesta & 21.42 & ao & 95 & 110 & 116 & 74 & 73 & 32 & 10 & 2007 & 0.000 & 111 \\
\hline Mataysia & 3005 & 36 & 93 & 100 & 100 & 72 & 70 & 33 & 27 & 2007 & 0.744 & 50 \\
\hline Phillppines & 1 ess & 94 & 94 & 100 & 100 & a7 & 70 & 32 & 25 & 2007 & 0.638 & 100 \\
\hline Thalland & 4036 & 92 & 96 & 108 & 100 & as & 78 & 46 & 3a & 2007 & 0.654 & 67 \\
\hline India & 846 & 51 & 76 & 100 & 114 & 49 & 53 & 10 & 14 & 2006 & 0.518 & 122 \\
\hline
\end{tabular}

Observing table 1 above where Indonesia's position of human capital is in the level of 111 is in the lowest level after India in the rank position 122, and Philippines in the position of 100 . Where the Philippines GDP is 1,639 still below of Indonesian GDP in the level of 2,142, but Philippines is capable to provide human capital higher than Indonesia while Indonesia with biggest demography with around 250,000,000 people inside. In actually can be the biggest human resources suppliers on the human capital development prospectively. It means in implementing the regulation as described above the human capital development become main the pillar handling and optimization of maritime field in Indonesia is very necessary and urgent, because the area for this is very extensive over marine Indonesian state and contains tremendous potential of biodiversity.

In the report of Deloitte, Cambanis, D. George (2011), that follow indicate table 2, nationalities for officers and ratings of those responding to our survey and give a sense of countries that are current sources of trained seafarers. Through this below table shows those Principal nationalities: officers; Philippines and India supply more the world fleet than any other country. This can be attributed to the several factors; these countries have made significant commitments to establish institutions to provide marine education, their populations have a good command of the English language and lastly, there is an absence of alternative employment opportunities within their borders.

Table 2. Nationalities for officers, current sources of trained seaferes

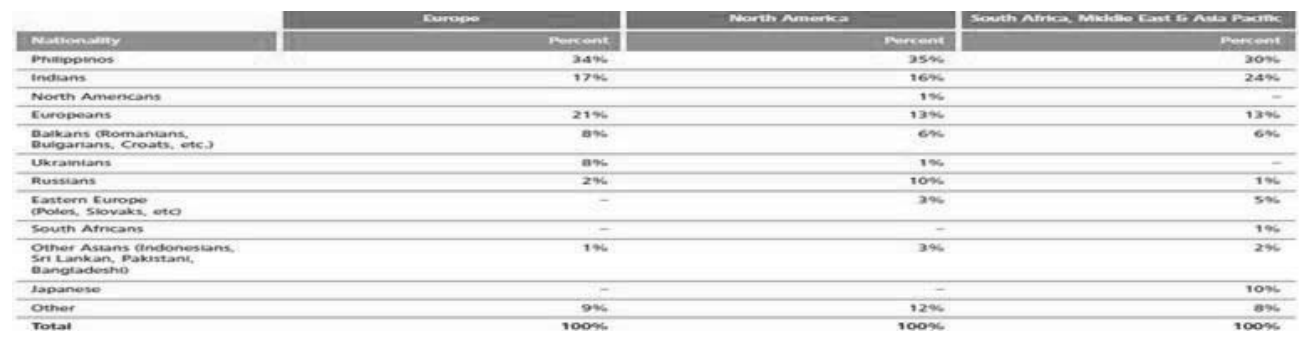

Source: Deloitte; Challenge to the Industry Securing skilled crews in today's market place.

Looking at table 2 above that the number of current sources of trained seafarers of the Philippines 34\% to Europe, $35 \%$ for North America, 30\% of South Africa, the Middle East and Asia Pacific and India 17\% to Europe, 16\% North America, $24 \%$ of South Africa, Middle East and Asia Pacific. While the rest of Europa; 21\% Europe, 13\% North America, 13\% South Africa, Middle East \& Asia Pacific Both countries which dominate while Indonesians, Sri Lankan, Pakistani, Bangladeshi only occupy 1\% Europa, 3\% North America, 2\% South Africa, Middle East \& Asia Pacific . Noting table 2 and the explanation, it is clear the State of Indonesia has not made the optimization of human capital for the Maritime 
Industry.

\subsection{Indonesia Potential Maritime and Fisheries Resources}

As well known that the country of Indonesia has the Potential Maritime and Fisheries Resources in the world, but until todays not yet optimized; it has 17,504 islands with 13,466 islands have been proven. It has $3 / 4$ is only $1 / 4$ of the ocean and land with an area of 1.91 million kilometer2, 104,000 kilometers of long coast (Adurrahman, Syahrin, 2014). Developing the Maritime Industry shall make in long term of national programs that must be realized as soon as possible because of the potential support for the advancement of the nation economic growth, biological resources, food resources and human resources is very large and contributes to the national income and human development as well.

\subsection{New Labour needs in Marine and Fisheries Sector Industries}

Based on BPS reported data, February 2014, the population of Indonesia earning as much as $181,169,972$ persons consisting of a labor force of 125,316,991 persons and for unlabored force of 55,852,981 persons. The total labor force, which works much 118,169,922 and unemployed people are 7,147,069. Skilled employments are still in the obstacle in improving the welfare of society in this country. Several factors are at issue in employment among others, are like the poor quality of labor, the labor force is not comparable with employment, labor distribution is uneven, and unemployment. (Lakip KKP 2015)

Table 3. Total Labour Marine and Fisheries Sector 2014

\begin{tabular}{clccc}
\hline No & Type of Labour & Target & Realization & $\%$ \\
\hline 1 & Education, training and extension & 2,450 & 2,525 & 103.06 \\
2 & People's Salt Enterprises & 14,000 & 15,876 & 113.40 \\
3 & Processing and marketing of fishery products & 62,520 & 63,085 & 100.40 \\
4 & Fish farmers & 146,282 & 147,585 & 100.89 \\
& Total amount & 219,252 & 229,219 & $\mathbf{1 0 1 . 7 0}$ \\
\hline
\end{tabular}

\section{Source: LAKIP KKP 2015}

Looking at table 4 above that what is programmed by the ministry of marine and fisheries in 2014 has been reached with $101.70 \%$. The number of new workers in the field of Marine and Fisheries Industry are growing, but while compared to the number of people that live in the side waters around the coast and in all regions of the republic of Indonesia is still a very small number. Meaning, it is needed to review the future workforce needs of marine and fisheries and other maritime fields so that the optimization of this field can be achieved.

Table 4. No. graduate education at the Marine Education and Fisheries in 2013 and 2014

\begin{tabular}{lcc}
\hline No Education Units & Graduates 2013 & Graduates 2014 \\
\hline 1 School of Sailing (higher education)-Jakarta & 334 & 320 \\
2 Polytechnic Marine and Fisheries & 232 & 310 \\
3 SUPM Marine and Fisheries & 829 & 1,035 \\
Graduates the Children of Main Beneficiaries Actors of Non Ministry of Maritime Affairs & 25 & - \\
and Fisheries. & 1,420 & 1,665 \\
Total Amount & \\
\hline
\end{tabular}

Source: LAKIP KKP 2014

Table 5. Absorption development of Labour and the New Marketers Fishery Product Year 2013-2014

\begin{tabular}{lccc}
\hline \multirow{2}{*}{ Key Performance Indicators } & \multicolumn{2}{c}{ Year } & \multirow{2}{*}{ Growth (\%) } \\
\hline The number of processors and marketers of Labor recently fishery & 2013 & 2014 & \\
\hline
\end{tabular}

Source: LAKIP KKP 2014 
In table 5 the increased number graduates only 245 persons during the year 2014, means still not significant to fulfill the national marine industry needs. And in table 6 above explains that the labor supply of new processors and marketers of fishery products in 2014 it increased to 8.83\% $(57,968)$ when compared to the year 2013, i.e. 57,968 people. These data indicate that the business sector processing and marketing of fishery products is quite interesting and growing, but still far from the nationally needs.

In the report of LAK Biro Kemenparekraf RI (2012) the implementation of the program has been carried out PKN 1,600 scholarships to children of fishermen with a budget allocation of IDR. 12 billion, which is expected to improve the quality of children's education so that the expected life of fishermen fishing families can be better. In addition to improving the skills and abilities of fishermen have conducted training in marine and fisheries to 12,000 fishermen with a budget allocation of IDR. 34.8 billion and carried out assistance through extension field of fisheries involving fishing 6,141 with a budget allocation. These programs are hoping to increase the marine human capital.

Table 6. Training Support for Minneapolitan

\begin{tabular}{cllcc}
\hline No & Province & Types of Training & Total trainee & Budget \\
\hline 1 & West Java & Training Zone Minneapolitan Cultivation and Processing & 530 & $1,090,000,000$ \\
2 & Central Java & Training Zone Minneapolitan Cultivation and Processing & 60 & $120,000,000$ \\
3 & West Sumatera & Training Zone field Minneapolitan arrest, machining, Cultivation and Processing & 120 & $367,944,000$ \\
4 & North Sumatera & Training Minneapolitan Region Processing field, machining and Aquaculture & 240 & $694,579,000$ \\
5 & Riau Islands & Training for Zone field cultivation Minneapolitan & 30 & $91,986,000$ \\
& Total & & 1,930 & $\mathbf{2 , 3 6 4 , 5 0 9 , 0 0 0}$ \\
\hline
\end{tabular}

Source: Lakip KKP 2012

There are only five Provinces in the nation involved the maritime training 1,930 trainees with consume 2,364,509,000.Indonesian Rupiah (IDR). In the future this number shall be increased and also the budget to respond the national maritime industry growth and development and to overcome the unemployment people inside the country. In the meeting material of Bank Indonesia (2014) reported that there are any growing number of Fisheries Extention persons from the year 2008 to 2013. The number is from 4,204 to be 9,671, for the a few islands in Indonesia; Sumatera, Java, Bali-Nusa Tenggara, Kalimantan, Celebes, Maluku and Papua. If it is compared to the number of the people around the whole coast of the islands in Indonesia can be said is still very far from the needs.

Table 7. Total Fish Processing Unit and Labour force

\begin{tabular}{|c|c|c|}
\hline \multirow{2}{*}{ Teritory } & \multicolumn{2}{|c|}{ Year } \\
\hline & Fish Processing Unit (000) 2012 & Labour force (million people) 2012 \\
\hline Total & 64.03 & 1.35 \\
\hline Sumatera & 15.70 & 0.29 \\
\hline Jawa & 28.43 & 0.70 \\
\hline Bali-Nusa Tenggara & 5.18 & 0.07 \\
\hline Kalimantan & 8.54 & 0.12 \\
\hline Sulawesi & 5.23 & 0.15 \\
\hline Maluku-Papua & 0.94 & 0.02 \\
\hline
\end{tabular}

Source: Meeting Material Bank Indonesia, Menado (2014)

Gaps towards the territories as displayed in table 8 comparing to the national wide of the country, fish processing unit toward labour force, it is figured that the total amount of labour force all over the nation is 1,35 million persons that means only approximate $0,54 \%$ persons of labour force in fish processing unit sector from all Indonesian people. The other gaps; there are 34 provinces in this country, but only 6 territories have Fish processing units so, there are many the rest territories still idle. If the rest ones optimize need people to occupy the demands. Due to the argumentations and results and discussion above it is proven that optimizing the maritime industries in a nation shall conduct the human capital development for sustainable, growth and development of the country itself. 


\subsection{Proposed Strategy Optimizing Marine Industry through Sustainable Human Capital Development}

Bappenas report (2014) efforts to build a modern developed nation through educational programs. As known that marine industry is a cyclical industry that can sustain from time to time; therefore it must be kept and maintained properly due to strongly support the national and global economy. Ernst and Young (2013) reported that increased capacity and Research and Development (R\&D) in the maritime sector can also support the activities of the blue growth also accelerated the maritime affairs innovation. Innovation in aquaculture and marine energy utilization requires collaboration with businesses. Therefore, human capital development, R\&D and growth of blue-based business incubator are needed supports the national universities, training providers, private organizations and also government. Marine industry is a cyclical industry; therefore it must be kept and maintained properly due to strongly support the national economy sustainability. Then the players in this industry and the government should really pay attention to human capital development so as not to depend on other nations or suppliers from other countries.

Proposed of human capital development programs are as follows: 1. Improving the quality and skills of human resources by increasing the proportion of the growth number of workers who are competent and recognized both nationally and internationally. 2. By involving higher education institutions, public and private training to be competencybased training institutions continuously improvement better than now curriculum. 3. Continuously and gradually develop regional and international competency standards (regional competency standard framework), for the services sector in the priority areas of maritime ASEAN economic community. 4. Implement the increased the growth competitiveness labour market efficiency either regional or international level; and number of formal workers in both the public and private sectors across the country planned area. 5. Conduct Indonesian National Qualifications Framework (KKNI) in the all of the institutions of higher education, training providers, and training venues designated to achieve high equality of recognition as proven and standardized. 6 . Improving the management of the maritime in all sectors related that able to develop the nation human capital and elevate the country maritime competitiveness.

\section{Conclusion and Recommendations}

As discussion and data analysis above, it is proved that the human resources and quality of marine industry still in the obstacle zone. To achieve this goal, it will be necessary to do inter-sectoral cooperation and coordination department by the central government under the control of the president goes along with the optimization of national development. Higher education and education centers was achieved in all regions that will be able to jointly envolved in order to achieve national development that is fair and equitable. Optimizing the existing maritime educations that national and international level needs to be planned to establish quality of the the maritme human resources in Indonesia. In enhancing the ssciences and technology and the increasing insight and maritime culture, suggest to focus on: (1) human capital on capacity building of marine and fisheries as optimum planned. (2) Improving of Marine Science and technology by involving the avail quality human resources; and (3) strengthening and revitalization of maritime educations, resources and culture.

Suggest and recommend for government to develop the Maritime Industry Resource governance, which emphasizes the development of qualified human resources, will facilitate the sustainable management of marine resources for the benefit of the people of Indonesia that will improve the competitiveness of the nation, national economy growth, and equitable development. The role of higher education institutions as human resource quality providers, through education become the most pivotal to answer the demands.

\section{References}

Abdurahman, S. (2014). Kebijakan Pembangunan Kelautan dan Perikanan. General lecture. Fakultas IImu Kelautan dan Perikanan, Universitas Hasanuddin, on 25 Maret 2014.

APEC (2014). APEC Ocean and Fisheries Working Group August 2014. Marine Sustainable Development Report Part 1.

Asyali, Ender (2010). Global Economic Crisis and the Impact on Human Resources Strategies for Seafarers. [Online] Available: http://www.pirireis.edu.tr/wp-content/uploads/ showcontent0007.pdf (November $25^{\text {th }}, 2014$ )

Bank Indonesia (2014). Percepatan Pembangunan Ekonomi Regional melalui Penciptaan Iklim Investasi dan Daya Saing Daerah. August $11^{\text {th }}$, at Manado [Online] Available: http://www.bi.go.id/Documents/DKEM.pdf (December 15 $\left.{ }^{\text {th }}, 2014\right)$.

Bappenas RI (2014). Rencana Pembangunan Jangka Menengah Nasional 2015-2019. Buku I

Agenda Pembangunan Nasional.

Barsan, E., F. Surugiu \& C. Dragomir (2012). Factors of Human Resources Competitiveness in Maritime Transport. [Online] Available: http://www.transnav.eu/(Oct. 11 $\left.1^{\text {th }}, 2015\right)$ 
Biro Perencanaan Kemenparekraf (2012). Laporan Akuntabilitas Kinerja Kementerian Parawisata dan Ekonomi Kreatif Republik Indonesia.

Bogdan, Robert C. dan Biklen, Knopp S. (1998). Qualitative Research in Education: An Introduction to Theory and Methods. Boston: Allyn and Bacon, Inc.

Cambanis, D. George (2011). Challenge to the Industry Securing skilled crews in today's market place. The Global Survey. [Online] Available: http://www2.deloitte.com/con-tent/dam Deloitte/global/08072013. pdf. (October 21st, 2014)

Cotten, A. (2007). Seven Steps of Effective Workforce Planning. Human Capital Management Series. [Online] Available. http://www. uquebec.ca/fichiers/pdf. (July 20, 2014).

Dervojeda, Kristina et al (2012). Extension of the European Cluster Observatory: Promoting better policies to develop world clusters in Europe. [Online] Available: WP2 Methodology Report. p.26. (January, 23rd, 2015).

Ernst and Young (2013). Shipping Industry Almanac. [Online] Available. http://www.ey.com /Publication/Shipping_industry_almanac:_ 2013. pdf (October 20th 2014$)$

Felicia, S. et al (2010). Impact of Seafarers Training on Crew Personnel Strategy and Compe-titiveness. Maritime Transport \& Navigation Journal, Vol. 2, No. 2. [Online] Available: http://www.ronomar.ro/resource/maredu/paper8.pdf (October, 23rd, 2014)

ILO (2013). Enhancing youth employability: The importance of core work skills. Copy right International Labor Organization. P.1-10

Kementerian Kelautan dan Perikanan RI (2015). Laporan Kinerja Kementarian Kelautan dan Perikanan tahun LAKIP KKP 2014.

Nadeak, B. \& Purba, J. T. (2014). Applied Management Strategy on Human Capital in Higher Education for Faculty Development in the Dynamic Service Industry: A case study. Journal of Content Business in Today's ICT Industry. No.1, Vol.1, pp. 58-66.

OECD (2013). Structural Policy Challenges for Southeast Asian Countries. Economic Outlook 2013: with Perspectives on China and India. [Online] Available: http://www. oecd.org/dev/asia-pacific/sae02013.htm ( January 10th , 2015)

OECD (2012). Kajian OECD mengenai Reformasi Regulasi. Indonesia Memperkuat Koordinasi dan Menghubungkan Pasar. Ringkasan Eksekutif. [Online] Available: http://www.oecd.org/gov/regulatory-policy/executive.pdf (October, 11 th , 2014)

Othman, R. M. (2014). UMT'S Future Maritime Education Programs in Enhancing Malaysians Competitiveness in the Maritime Industry. Journal of Business and Social Development. Vol. 2 No. 2, September:9-19. [Online] Available: http://jbsd.umt.edu.my/w pcontent/uploads/sites/53/2014/11/2.pdf (September 25 th, 2014 )

Purba, J. T. (2014). Enhancing ICT Competencies through Education as a Strategy in Facing Regional Opportunities and Challenges. Paper Presented in the $3^{\text {rd }}$ International Conference on Business at Binus University, Jakarta, on September 1st-2 ${ }^{\text {nd }}, 2014$.

Reaves, Celia C. (1992). Quantitative research for the behavioral sciences. New York: John

Wiley, 1992.

Suprapto, Djoko (2002). Optimizing Marine Resource Exploitation towards a Sustainable Cur. Development. Journal of Southeast Asian Education, Vol. 3, No.2, pp. 225-244.

Surya, A.C.T. (2014). Optimalisasi Pembangunan Kemaritiman Nasional. Info Singkat. Ekonomi dan Kebijakan Publik. Vol. VI, No. 20/II/P3DI/Oktober/2014. 